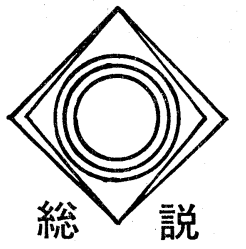

バイオマス生産とバイオマス変換

\section{1. バイオマス量}

まず，地球上飞生育あるいは堆積しているすべての 生物有機体すなわちバイオマスをエネルギーとして見 積ってみることにする。細か度数值をあげることは意 味がないし，正確な評価は困難であるので，大雑把な 概念を得るための見積りである。そこでその基準とし て世界の年間のエネルギー消費量を一単位とすると, 全世界のバイオマスを燃焼して得られるエネルギーは 約 100 単位に相当する。換言すれば，世界のエネルギ 一消費量を全部石炭 (炭素) でまかなったとすれば, その量すなわち約 $10^{10} \mathrm{tC}$ の約100倍の炭素がバイオマ スとして地球上に現存しているということになる。そ こで次に種々のエネルギー資源を炭素量に換算して上 記の単位で相対值を求めてみると, なず年間に地球上
理 研 化学研 究所* 柴 田和 雄

に降る太陽エネルギーをすべて有機物に变換すること ができたとすると，その量は約 10,000 単位に相当す る。ところで害際に光合成によって, 毎年植物有機体 (ファイトマス) になるのは約10単位であって，した がって地球上の植物によって捕えられ有機物の化学エ ネルギーに変換される太陽エネルギーは約 $0.1 \%$ にす ぎない。これを上記のバイオマス量と比較すると，光 合成による年間のバイオマス生産 (一次生産) の約10 倍がバイオマスとして存在していることになる。バイ オマスには動物や微生物などのあらゆる生物有機体が 含まれるけれぞも(化石資源は含まれない)，その大部 分は植物によるファイトマスである。光合成の炭素源 は炭酸ガスであるが, 大気中の $\mathrm{CO}_{2}$ 抢よび海洋に溶存 している $\mathrm{CO}_{2}$ の量はそれぞれ約 100 単位に相当する。

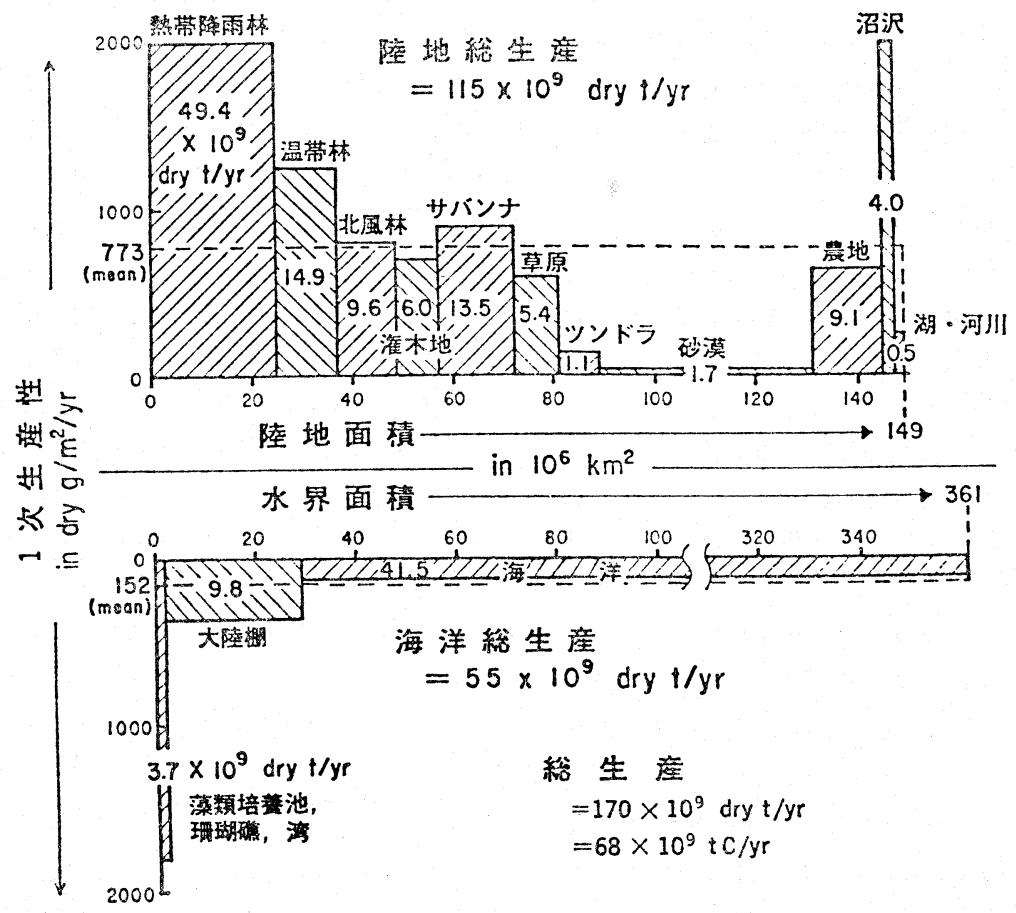

図 1 陸地および水界における生産性と総生産

* 埼玉県和光市広沢2-1 
すなわち，炭素量としてバイオマス量にほほ等しい。 また現社会の主要なエネルギー源である化石資源の推 定埋蔵量は約 100 単位前後で, これもバイオマス量に ほぼ相当する。今後ぞれでけ新しい化石資源が発見さ れるかわからないが，試掘による発見率の減少を考兄 ると多くを期待することはできない。このようにバイ オマスの絶対量は大変大きく, しかもその1/10が毎年光 合成によって再生されている。いっ湮う，太陽エネル ギーのバイオマス・エネルギーへの変換効率は上記の ように低いけれどる, これは逆に今後の開拓の希望と 可能性を示していると考えてよからう。

光合成による 1 次生産の生産性を上げるためには, ぞの上うな所で生産性が高いか，あるい怟いかを知 る必要がある。図 1 は生態系別の 1 次生産性を示した ものである。陸地における生産性は森林特に熱带降雨 林に高く, 農地の生産性よりも高いことは注目すべき ことである。海洋では外洋の生産性が栄養源の不足の ため, 大陸棚よりも低い。陸地の総生産は海洋の約 2 倍 で, 両者を合わせた年間の総生産は乾燥有機物重量と して $17 \times 10^{10} \mathrm{t} /$ 年，炭素換算すると $7 \times 10^{10} \mathrm{tC} /$ 年とな $り$ ，上記の概算相対値の約 10 単位 $\left(10 \times 10^{10} \mathrm{tC} /\right.$ 年 $)$ と なる。

\section{表 1 エネルギー資源の炭素（石炭）換算による 概算比較表}

世界年間エネルギー消費量（炭素換算約 $1 \times$ $10^{10} \mathrm{tC} /$ 年)を 1 単位とした場合のその他の資 源の炭素換算相対値。

\begin{tabular}{lc}
\hline \multicolumn{1}{c}{ エネルギー資源 } & 相対值 \\
\hline 世界年間エネルギー消費量 & 1 \\
世界年間食糧消費量 & 0.05 \\
年間太陽エネルギー照射 & 10,000 \\
地球上のバイオマス & 100 \\
光合成による年間一次生産 & 10 \\
大気中の $\mathrm{CO}_{2}$ & 100 \\
海洋溶存 $\mathrm{CO}_{2}$ & 100 \\
化石資源推定埋蔵量 & 100 \\
\hline
\end{tabular}

\section{2. バイオマスの洒值}

そもそも炭酸ガス, 水などの無嘰物を原料として植 物が行っている光合成の産物, すなわち有機物には, 三つの価值がある。一つはエネルギーとしての価值 で，たとえば主産物の炭水化物が炭酸ガスと水から合 成されるには, 炭酸ガス $1 \mathrm{~mol}$ 当り $114 \mathrm{kcal}$ のェネ ギーを必要とする。それだけ炭水化物のほうがェネル ギーが高いのである。植物はこの合成のエネルギー源 として，太陽光のエネルギーを利用している。

$$
\begin{gathered}
\mathrm{CO}_{2}+\mathrm{H}_{2} \mathrm{O} \underset{\text { 哦 吸 }}{\stackrel{\text { 光合成 }}{\leftrightarrows}} 1 / 6\left(\mathrm{C}_{6} \mathrm{H}_{12} \mathrm{O}_{6}\right)+\mathrm{O}_{2} \\
\Delta \mathrm{F}=+114 \mathrm{kcal} / \mathrm{mol}
\end{gathered}
$$

この反応では, 同時に生物の呼吸に必要な酸素が発 生する。動物はそのエネルギーを有機物から得てお り, 呼吸, すなわち有機物の生体内酸化によって発生 するエネルギーを利用して生命の維持, 活動, 繁殖を 図っている。ここに有機物の第二の価值，すなわち食 物(食糧)としての価值がある。第三は, 物質資源とし ての価値である。石油などの化石資源が経済的にある いは供給源として利用しがたくなったときには, 現在 石油から合成している多くの生活必需品を光合成産物 から合成する途がある。炭酸ガスから合成する方法も あるけれぞも，化石資源が過去数億年にわたる光合成 産物の蓄積であることを考觉ると, 生物依存するの が自然な方策といえよう。また木材を建材として利用 して来たことは云ら李でもない。

\section{3. 光合成の利用}

それでは，光合成は今後どのように役立つであろう か, 植物における光合成の機構が順次明らかになるに 及んで, 光合成システムを, 未来永劫の clean で renewable なェネルギーと資源を得るために利用しょ らとする研究と開発が, 種々の分野で進められてい る。表 2 は，そのエネルギー源である太陽エネルギー の利用を，天然系と人工系とに分類して表示したもの である。地球上飞到達する太陽エネルギーは, 可視, 紫外部の光として利用できるものが約半分で，残りの 半分は熱として利用できる近赤外線であって，それぞ れの特徴を生かした利用法がこの表に示されている。

光合成利用の途は多種多様あるけれども, ここで述 べる自然界の光合成あるいは人工光合成を盛んにする 方策, すなわち光合成㙨構の直接の利用と, 後述する 光合成産物，すなわちバイオマスの利用とに分けられ る。

機構が明らかになれば，それをもとにして植物の生 産性を高める方策を立てることができる。炭酸ガス， 水，窒素源などの原料がどのようにして生体に吸収さ れ，太陽光のエネルギーによっていかに有効に有機物 飞変換されるかといらメカニズム，すなわち工場でい えば，製造法と生産過程の解明炕よって生産の向上を 罒ろらといらのである。また，合成した有機物を運ん で䝪蔵したり，あるいはこの収入の一部を工場の運営 に利用することも植物は行っているけれども, その際, 無䭾な消費（呼吸）をせずに貯蔵することも大切であ る。かくして合成された有機体は植物自身であり，見 
表 2 光エネルギーと熱エネルギーの現在および将来の利用法

\begin{tabular}{|c|c|c|}
\hline 変換系 & 光 利 用 & 利 \\
\hline 天然変換系 & 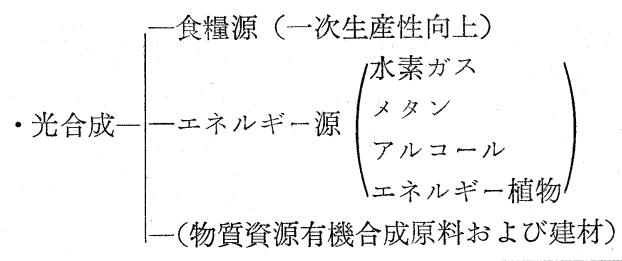 & $\begin{array}{l}\text { • 水力発電 } \\
\text { - 風力発電 } \\
\text { ·波力発電 } \\
\text { ·海洋温度差発電 }\end{array}$ \\
\hline 人工変換系 & $\begin{array}{l}\text { - 光化学的水素生産 } \\
\text { - 人工光合成 } \\
\text { - 光化学電池 } \\
\text {-太陽 電池 } \\
\text { • 光化学的エネルギー貯蔵 }\end{array}$ & $\begin{array}{l}\text { · 太陽炉(水の熱分解による氷素生産) } \\
\text { • 太陽熱発電 } \\
\text { ·太陽熱冷暖房 }\end{array}$ \\
\hline
\end{tabular}

方を変えれば，工場自身も光によって構築されると考 えらる。この工場の動力は太陽土ネルギーであるが， その管理も光によって行われている。すなわち, 明暗, 光の強弱，波長変化によって光合成抢よびそれに関連 する機構のいろいろな部分が制御調節されている。た とえば, 光の強弱に応じて細胞中の葉緑体は自ら配列 変えを行って，光をなるべく一様に分布吸收するよう に働くとか，炭酸ガスの吸収口としての葉面の気孔は 明で開き，暗で閉じ，炭酸がスが不足すれば暗所でも 開くといらように，たいへん都合のよい働きをしてい る。また, 合成される蛋白質と炭水化物の比率は青色 光によって制御されている。このような制御調節信号 としての光の作用も，そのメカニズムが詳しくわかれ ば，人為的に植物をコントロールすることがすすます 容易になるはずである。

生物体を直接利用しようとする以上の方策と対照的 なのは，人工システムの開発である。人工光合成系と でもいうべきこのシステムによって，光のエネルギー を化学ェネルギーに変換しようといらのである。ただ し，その開発には生物の光合成から大いに学ぶ必要が あり，この意味で光合成機構の利用とみなすことがで きる。このシステムでは, 水を光分解して水素をつく ることがまず考えられている。そもそも生物の光合成 は，水を光によって還元物質と酸素に分解し，この還 元物質によって炭酸ガスを有機物に還元する反応であ る。ところで，この還元物質によって水素イオンを還 元したとすると, 水素が得られるわけで, 結瓶, 水が 光によって水素と酸素に分解されたことになる。事 実, ある種の藻類は嫌気的状態にすると, 有機物を生 産するかわりに水素を発生する。したがって, 生物的 に光によって水から水素と酸素をつくることもでき
る。人工光合成では，この反応を酵素モデルとしての 各種の合成錯体を合成高分子膜中に一定の配列で埋込 んで，細胞中の生体膜と同じょうに，光合成あるいは その一部の反応を行わせようとするわけである。ただ し, 水素は然焼させれば水になる clean なエネルギー 源であるが，食物や有㙨資源としての価值はないし， もち運ぶにも有㙨物のほうが便利である。また，この よらな人工システムによって，電気エネルギーを得る こともできる。光合成の初期反応は, 太陽電池のよう に生体膜中における光による電荷分離の反応であるこ とから考えると，このシステムも一種の人工光合成系 とみなすこともできよう。この系には, 太陽電池のよ らに乾式の方法と, 光化学電池のような湿式の方法と がある。ただし，電気エネルギーはその場で利用する ときには便利であるが，貯蔵しようとすると重い電池 が必要になる。

\section{4. バイオマスの利用}

人類は農耕によって食糧を得てきたが，食物がわれ われにとって最も重要な光合成産物の役割であること には変りはない。人間が手によって作物を育てるとい ら農業的アプローチは, 水, 肥料, 温度などが不足す ればこれを与えるというように，ストレスの除去から 始まり，現在ではあらゆる手段で育種育生を図ろらと する近代農業へと発展を遂げてきた。ただし，今後配 慮すべきは，投入エネルギーとそれによる増収との関 係である。投入エネルギーを光合成蓄積物としての化 石資源に頼るとすれば，当然収支を考えなければなら ないはずで，将来困ったことになる可能性があるから である。また，食物としてだけでなく，エネルギー源 めるいは有機資源として植物を育てる必要性も生じて くる。たとえば，石油のような炭化水素を樹液として 
産生する植物（エネルギー植物）を高収率で育てる研 究もすでに進められている。

このように，目的とする植物を育て，利用しょうと する旧来のアプローチに対して, 自然のままの光合成 産物を利用しよらとするもら一つのアプローチが存在 する。この方策に意味があるのは，自然林その他の天 然生態系の生産性が農業よりも高いといら事実がある からである。資源が豊富であったときには省みられな かった自然界の有機物を化学的に利用の途を広げるこ とによって，多量な資源として活用しようというわけ である。たと党ば, 葉の蛋白質の利用とか, 高活性セ ルラーゼの開発による繊維の利用など,この面に抢け る新しい発想と研究の伸展が望ま机ている。

表 3 バイオマスの燃料化

\begin{tabular}{|c|c|c|}
\hline 資 & 方 & 生成物 \\
\hline \multirow{3}{*}{$\begin{array}{l}\text { 乾燥バイオマス } \\
\text { (木材, 廃材その他) }\end{array}$} & 直 接燃燒 & 熱, 電気 \\
\hline & ガス化 & $\begin{array}{l}\text { ガス燃料 } \\
\text { メタン } \\
\text { メタノール } \\
\text { アンモニア }\end{array}$ \\
\hline & 熱 分 解 & 油, ガス,木炭 \\
\hline $\begin{array}{l}\text { 含水バイオマス } \\
\text { (污水, 廃液, 藻類) }\end{array}$ & 嫌気的醱醇 & メタン \\
\hline $\begin{array}{l}\text { 炭水化物 } \\
\text { (デン粉, 糖, セルローズ) }\end{array}$ & \begin{tabular}{|l|} 
醱酵 \\
化学的分解
\end{tabular} & エタノール \\
\hline エネルギー植物 & 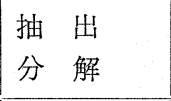 & $\begin{array}{l}\text { 炭化水素 } \\
\text { 油 脂 }\end{array}$ \\
\hline 水 & \begin{tabular}{|l|} 
光合成反応 \\
光化学反応
\end{tabular} & 水 素 \\
\hline
\end{tabular}

表 3 はバイオマスから然料を得るための多くの可能 性を示したものである。森林の生産性が高いことを考 えると木材を利用することがまず考光られる。木材か らのウッド・チップあるいはそれを成形したものを直 接燃焼する方式, あるいはガス化する方法, また油, 木炭，煉炭を得る方策がある。また Calvin 教授によ って提唱されている炭化水素を直接植物によって作ら せる方法についても，その実用化の可能性を各地域で 追究してみる必要がある。この場合, 生産物は必ずし も炭化水素でなければならないことはない。同程度に 燃燒熱の高い油脂を生産する植物の探究と栽培も必要 であろう。この意味では石油植物と云うよりもェネル ギー植物とでも呼んで方が適切であろう。
含水のバイオマスに対しては嫌気的醱酵によってメ タンを得る方式が既にドイッなどで，都市污水につい てかなりの規模で実用化され、メタンからの発電が行 われている。近い将来の代替エネルギーとして，現在 その広範囲の実用化が期待されているのは炭水化物か らのエタノール生産である。かつて瞪酵アルコールか ら合成アルコールへの転換が単に価格の小差で短期間 に行われたことを考光ると，原油の価格上昇あるいは 供給制限によって逆の転換を迫られる日も遠くはない ようである。既にガソリンに20\%のエタノールを混ぜ ガスホールとして自動車然料に使用している国はブラ ジルだけではないし，またブラジルではドイッ，アメ リカなどで $100 \%$ アルコール用に設計された車も走っ ている。ブラジルの醱酵原料はサトウキピで，そのた めのサトウキビ栽培が行われているし，マンジョカ (キャッサバ) 栽培についても研究されている。デン 粉, 裾などの炭水化物からの醊酵については既製の技 術を用いることができるが，セルローズの利用につい ては今後の研究に待つ面が多い。木材の糖化にはリグ ニンの分解あるいは除去が問題である。酔素により分 解する方法, 塩酸により分解して塩酸をりサイクルす る方法などが研究されている。各種の廃棄物中のセル ローズの液体然料化に成功すれば，われわれは大変な エネルギー源を得たことになる。

次は物質資源としてバイオマスを利用する方策であ る。あたかも石油化学工業和いてまずエチレンなど の合成原料を原油から取るように, 熱分解, 水添, 化 学的分解, 醱酵などの各種の手段によってまず必要な 合成原料を得ることが第一歩である。そのための熱 源, 電源などのエネルギー源も勿論バイオマスから供 給することになるであろう。その結果として得られた 水素, メタン, メタノール, エタノール, アンモニア, あるいはりグニンやロジンなどからの中間分解物を用 いて，われわれの生活に必要なあらゆる有機物を合成 する有機合成工業が発生することが予期される。もち ろん，糖や油脂なぞの比較的低分子のバイオマス原料

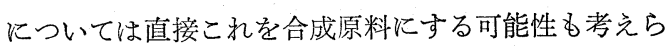
れる。云わば従来の石油化学工業に対して生物産業あ るいはバイオマス産業とでも云うべきものが発生発展 して行くであろら。このバイオマス産業はバイオマス 生産とその利用すなわち, バイオマス変換とを共に含 む, 従来の農業とも工業とも云兄ない, 両者を一体化 したような産業になる可能性がある。表 4 は以上の観 点を要約したものである。

\section{5. バイオマス利用の特徽}


表 4 過去, 現在, 未来のバイオマスの利用
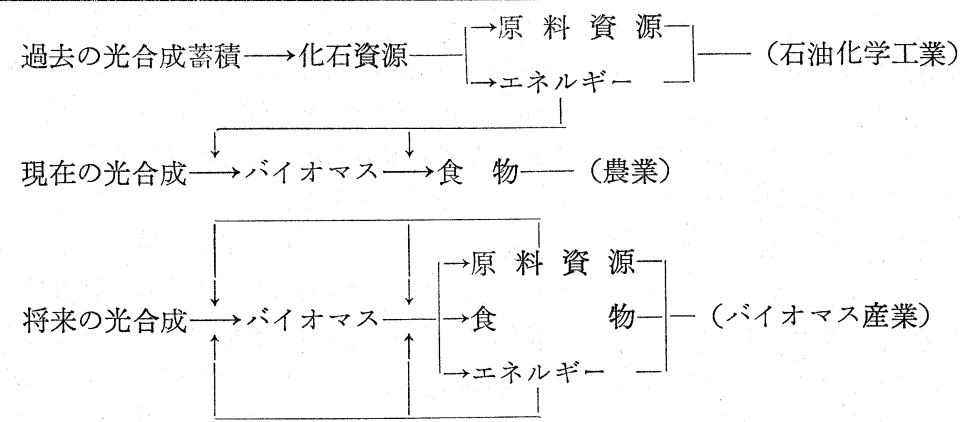

すでに述べたことから明らかではあるが，バイオマ ス利用の特徴を要約すると,

i）まずバイオマスはそれ自体貯蔵された形体になっ て打り，運搬が可能である。

ii）しかも, 上述のように食糧, エネルギー, 物質資 源として三様に利用することができる。したがって， 将来は食糧としてだけではなく, エネルギーや物質 資源として利用するためのバイオマス生産が考えら れる。

iii）太陽光の尽きないエネルギーによって生産され， バイオマス変換によるリサイクルの過程を経て再生 されるから，物質資源としてもつきることがない。 これは工業における一方向の直線的物質生産と対照 的で, フィード・バックシステムの生産と見ること もできる。

iv）太陽光利用の立場からすると, 面における生産で あって，都市すなわち点を中心とする今迄の工業と 対照的である。したがって, 面積を必要とし, その 結果として地域的に発達せしめることが大切になっ て来る。また生産したバイオマスを変換利用する場 合にも, 地域的に小規模で処理をしないと, 都市に 集中して利用しょらとすると運搬のエネルギーを要 することになり，利用の意味がなくなる。

v）バイオマス生産には水, 肥料その他のエネルギー や資源を要するが，この際の投入エネルギーと産出 エネルギーとの関係を検討をしないと，意味のない 生産を行ならことになる。

vi）バイオマス生産は地域の気候風土環境に大きく左 右されるから，それぞれに応じて適切な植物を育生 し，年間を通じて土地を利用するように計画するこ とが大切である。この点では, バイオマスは適時䝰 蔵される形体であり，乙か子気候風土に適応して色 々な植物が存在し, 育つことは有利な条件になって いる。

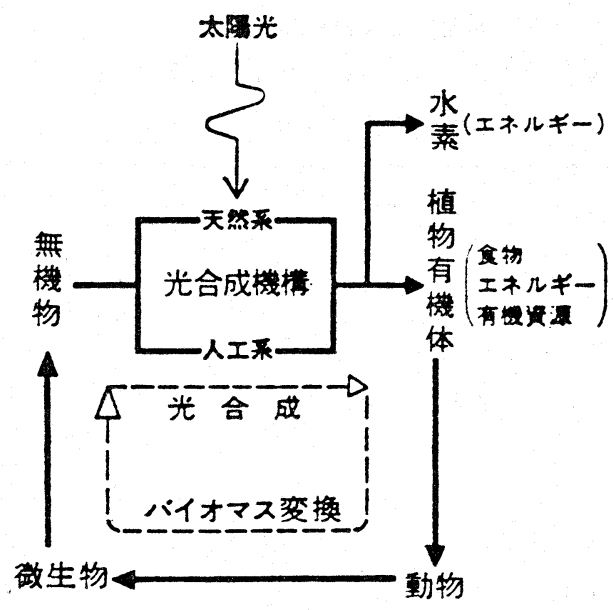

図 2 光合成とパイオマス変換

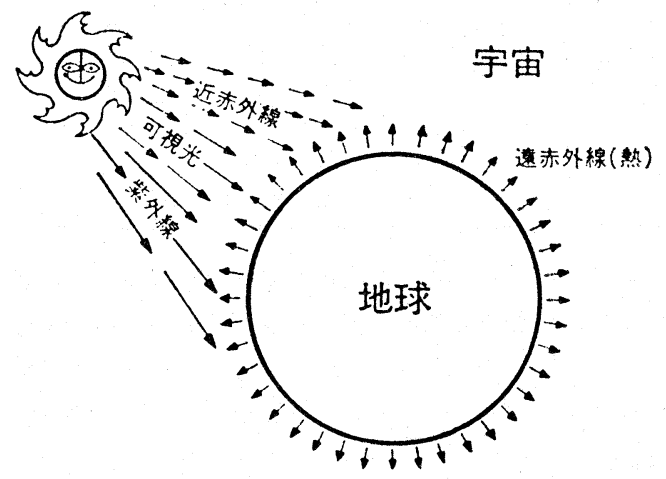

図 3 地球における放射エネルギーの流出入

vii）バイオマス生産とバイオマス変換とは生態系のサ イクルそのものであって, 特別な公害を起す心配が ないばかりでなく，下述のように生物繁栄の本質に 密着した重要なサイクルである。植物体は動物, 微 生物を経て再び無機物にもどるけれども，その中間 において必要な資源あるいはエネルギー源として利 
用しようというのが人工的バイオマス変換の使命で ある。バイオマス変換は消費を少なくすると同時に 新たに資源やエネルギーを生むということに意義が ある。

\section{6. 太陽光と生物の繁栄}

太陽光エネルギーが未来永劫のエネルギ一源である といわれるゆえんは, 単に clean で renewable であ るだけでなく，生物繁栄の本質に密着したエネルギー 源であるからである。生物がその固有の生体構造を維 持し生きるといらことは, 熱力学的にはその“低ェン トロピー状態”を維持することであり, 逆に生体構造 がくずれ，構成原子や分子が乱雑な配置をとり，エン トロピーが増大することは死を意味する。光も, とり 込むだけで，無駄に熱エネルギーに変換すると，エン トロピーは増大する。生きるため,すなわち, 低エント ロピー状態を維持するためには, その系 (個体)を通 してェネルギーを流し，有効に利用することが必要で
ある。植物体の場合の流入エネルギーは光であり, 動 物では食物の化学エネルギーであって, 熱や低分子物 質の排出および生物的仕事によってエネルギーの流出 が行われている。同一のことは，生物の集合である地 球生物圏全体についてもいらことができる。この場合 の流入は太陽エネルギーで，流出は昼夜を問わず宇宙 へ放射している遠赤外線の熱エネルギーである。結 局, この巨大なエネルギーの流れが上記の生態系サイ クルとかみ合って地球上の生物の繁栄を支えているわ けで, 低エントロピーの光による光合成はこのサイク ルへのエネルギーのとり込み口としての意義があり， バイオマス変換は生産された資源, 固定されたエネル ギーの有効利用である。エネルギー問題は熱力学の第 一法則（エネルギー保存則）はもちろんのこと，第二 法則 (エントロピー則) をも充分に考虑して解決すべ き問題である。

\title{
Biomass Production and Biomass Conversion
}

\author{
Kazuo SHibATA
}

(Institute of Physical and Chemical Research)

1. The amount of biomass available on the earth.

2. Three values of biomass: i) food, ii) energy and iii) materials (raw organic materials and timber)

3. The use of photosynthesis mechanism for high production of biomass and for production of hydrogen.

4. The use of biomass for energy (heat, electricity, mixed gases, hydrogen, methane, methanol, ethanol, hydrocarbons, fats, charcoal and briquette) and chemicals.

5. Developement of biomass industry and its characteristics.

6. Solar energy and creatures on the earth. 